\title{
Modulating Protein-Protein Interactions by Cyclic and Macrocyclic Peptides. Prominent Strategies and Examples
}

\author{
Rosario González-Muñiz *D, María Ángeles Bonache and María Jesús Pérez de Vega (D) \\ Instituto de Química Médica (IQM-CSIC), Juan de la Cierva 3, 28006 Madrid, Spain; \\ angelesbonache@iqm.csic.es (M.Á.B.); pdevega@iqm.csic.es (M.J.P.d.V.) \\ * Correspondence: iqmg313@iqm.csic.es; Tel.: +34-912-587-434
}

\begin{abstract}
Cyclic and macrocyclic peptides constitute advanced molecules for modulating proteinprotein interactions (PPIs). Although still peptide derivatives, they are metabolically more stable than linear counterparts, and should have a lower degree of flexibility, with more defined secondary structure conformations that can be adapted to imitate protein interfaces. In this review, we analyze recent progress on the main methods to access cyclic/macrocyclic peptide derivatives, with emphasis in a few selected examples designed to interfere within PPIs. These types of peptides can be from natural origin, or prepared by biochemical or synthetic methodologies, and their design could be aided by computational approaches. Some advances to facilitate the permeability of these quite big molecules by conjugation with cell penetrating peptides, and the incorporation of $\beta$-amino acid and peptoid structures to improve metabolic stability, are also commented. It is predicted that this field of research could have an important future mission, running in parallel to the discovery of new, relevant PPIs involved in pathological processes.
\end{abstract}

Citation: González-Muñiz, R.; Bonache, M.Á.; Pérez de Vega, M.J. Modulating Protein-Protein Interactions by Cyclic and Macrocyclic Peptides. Prominent Strategies and Examples. Molecules 2021, 26, 445. https://doi.org/ $10.3390 /$ molecules 26020445

Academic Editors: Maria Emília de Sousa, Katalin Prokai-Tatrai, Paula A. C. Gomes, Stefania Galdiero, Sandra Gemma, Mariana Spetea and Anne Roivainen

Received: 29 December 2020 Accepted: 13 January 2021 Published: 16 January 2021

Publisher's Note: MDPI stays neutral with regard to jurisdictional clai$\mathrm{ms}$ in published maps and institutional affiliations.

Copyright: $\odot 2021$ by the authors. Licensee MDPI, Basel, Switzerland. This article is an open access article distributed under the terms and conditions of the Creative Commons Attribution (CC BY) license (https:// creativecommons.org/licenses/by/ $4.0 /)$.

Keywords: cyclic peptides; macrocyclic peptides; protein-protein interactions; computational design; biochemical methodologies; synthetic strategies; cell penetrating conjugates; peptoids

\section{Introduction}

Medicinal chemistry programs focused on the search for protein-protein interaction (PPI) modulators are pursued by either academic and pharma/biotech companies [1,2]. The motor of this interest is the wide implication of PPI networks, the so called interactome [3], as regulators and executors in almost all biological processes, including cell signaling, survival, and proliferation, as well as pathogen-host recognition, among others. Only a few therapeutically relevant PPIs have been identified to date, so the interactome remains mainly unexplored and could be the foundation to design new drugs for unmet medical needs [4].

The interaction between two proteins normally involves a large and relatively flat surface, although certain nodes (hot-spots) could contribute in a special manner to maintain the protein-protein contact $[5,6]$. In this sense, peptides constitute a primary source of modulators for disrupting/stabilizing PPIs since they can be prepared in different length and amino acid composition by relatively simple, routine methods [7]. Peptides normally are endowed with high flexibility, resulting in low selectivity, and poor metabolic stability. Along with the backbone modifications, cyclization is one of the most popular structural changes to improve pharmacokinetics in peptides [8,9]. In this context, cyclic and macrocyclic derivatives attract much attention as valuable scaffolds for targeting PPIs $[9,10]$. They represent a halfway between biologic and small-molecule drugs, more accessible synthetically than the former, facilitating medicinal chemistry programs, and bigger in size than the latter (3-5 times larger), allowing them to interact with wide surface areas, which usually are needed for strong PPI interactions [11,12]. In fact, structural studies on cycle/macrocycle-protein complexes revealed that their surfaces are similar in size to native PPI interfaces and antibodies [13]. In addition, cyclic and macrocyclic peptides have 
conformational rigidity that control defined 3-D orientations of amino acid side-chains, and have more resistance to proteases than linear peptide counterparts. For these reasons, they are considered promising candidates for the development of chemical probes and novel therapeutics $[14,15]$. Among natural product macrocycles and cyclic peptides, there are about 68 marketed drugs and 40 more under clinical development [16,17], including the well-known examples cyclosporine A, caspofungin and daptomycin.

Nonetheless, there are some drawbacks for the implementation of cyclic and macrocyclic peptides as a more general strategy to PPI modulation and their translation into suitable drugs. Among them, the challenging synthesis, with a few, fast general methods to obtain large cycles in a convergent manner [18-20], the difficulties to get crystal structures of their complexes with interacting proteins, and their impermeability to the cell membrane preventing entry to intracellular targets [21].

More than an exhaustive review on cyclic and macrocyclic peptides described to interfere within PPIs in the last 10 years, this review wants to call the attention on some recent, innovative strategies and outstanding examples around this topic. The design directed by computational methodologies or based on PPI X-ray structures, the isolation from natural sources, and both biochemical and synthetic approaches to cyclic/macrocyclic peptides are considered here. The conjugation with CPPs to facilitate cell permeation, and the properties of some peptoid analogues are also mentioned. Stapled-type cyclic peptides for stabilizing helical conformations will marginally covered in this compendium because the high number of revisions appeared in the contemplated time lapse [22-27].

\section{Main Methodologies to Cyclic and Macrocyclic Peptides}

Amide head to tail, head/tail to side-chain, and side-chain to side-chain cyclization, along with disulfide formation, are conventional approaches normally used to generate mono- and polycyclic peptides [28]. Additionally, the incorporation of non-proteinogenic amino acids containing different functional groups is being increasingly explored to facilitate other ways of cyclization (i.e., stapled peptides) [23]. The development of various synthetic methodologies to generate macrocycles through the cyclization of peptides with different organic frameworks is also the subject of much attention in recent times [10]. In this section, we provide some wide ranging examples of bioactive cyclic and macrocyclic peptides and the different strategies to reach them.

\subsection{Computer-Assisted and X-ray-Based Design}

Computational techniques, combined with solid-phase peptide synthesis and different biophysical characterization methods, have been used to predict non-discovered PPIs, to identify PPI surfaces, to validate experimental results, and to virtually screen libraries of linear and cyclic peptides. Thus, computer simulation through structure-based design tools is in the origin of cyclic peptides that behave as PPI modulators, with several examples of computational screening approaches recently reviewed [29-31]. To exemplify this topic, from a model macrocyclic peptide able to bind 14-3-3 proteins, Kruger et al. generated a virtual library of $>1400$ stapled cyclic peptides including non-natural amino acids [32]. The interaction of $14-3-3$ proteins with the transmembrane receptor aminopeptidase $\mathrm{N}(\mathrm{APN})$ prompts an intracellular signaling cascade, activating the expression of matrix metalloproteinases (MMPs) [33], which are important modulators of the extracellular matrix, and are upregulated in rheumatoid arthritis and metastatic cancers. Therefore, the inhibition of extracellular PPIs involving $14-3-3$ proteins can decrease MMP transcription levels. Library filtration through docking scores and combination of the best modifications allowed the identification of higher affinity peptide derivatives, like compound $\mathbf{1}$ (Figure 1). This hydrocarbon-stapled peptide displays higher affinity than the model macrocyclic peptide for $14-3-3 \zeta$ protein, and is able to significantly reduce MMP1 transcription. Xray crystallography confirmed then the binding mode, thus verifying previous docking results [32]. 


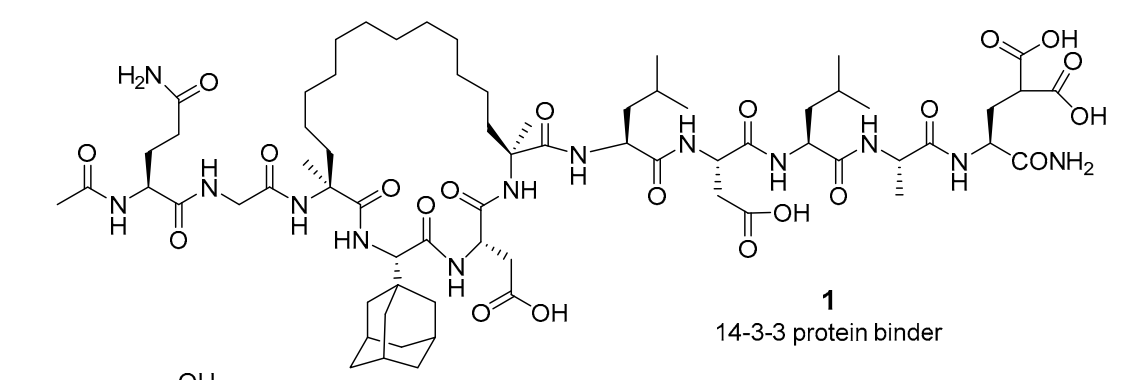

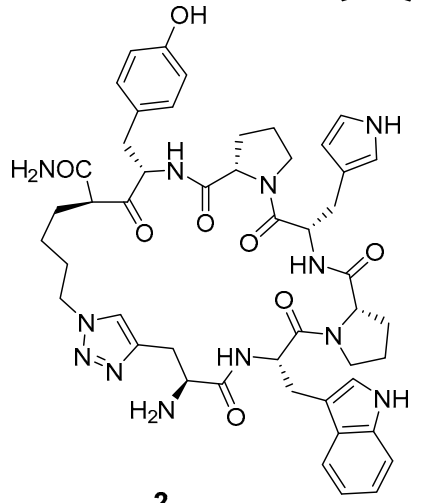

2

proMMP2-TIMP2

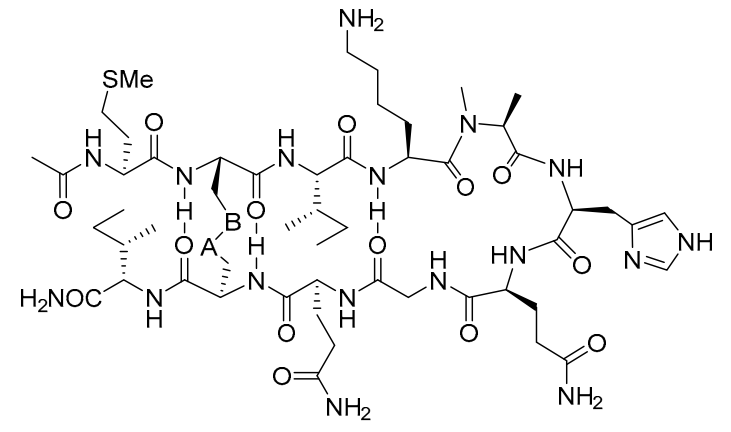

3: $\mathrm{A}-\mathrm{B}=\mathrm{CO}-\mathrm{NH}, \mathrm{NH}-\mathrm{CO}, \mathrm{CH}=\mathrm{CH}, \mathrm{CH}_{2}-\mathrm{CH}_{2}$, S-S

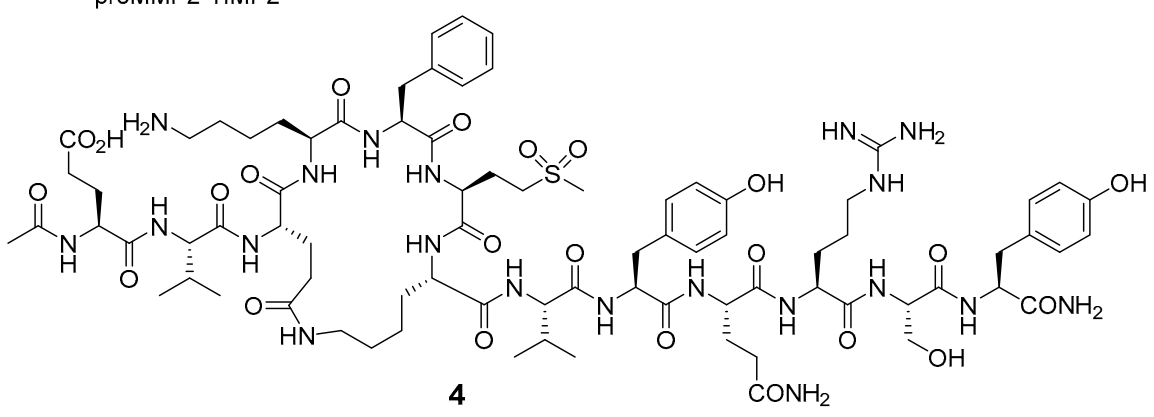

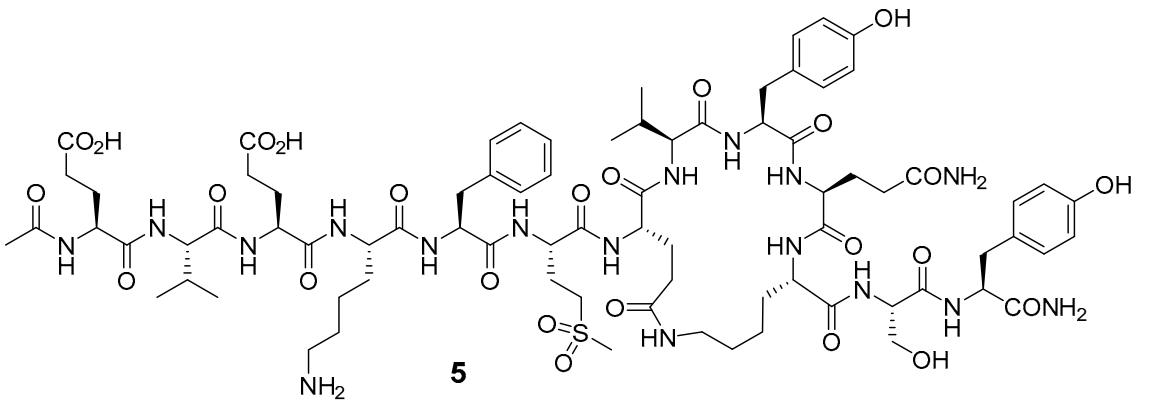

Figure 1. Cyclic peptides obtained after computer simulations or designed from protein-protein interaction (PPI) X-ray structures.

As an alternative approach to target metalloproteinases actions, the group of Ming Xue designed an epitope-targeted library of cyclic peptides to interfere within the interaction between tissue inhibitor of metalloproteinases-2 (TIMP2) and proMMP2 [34]. Cyclic peptide derivative 2 , with a triazole stapled linker, induces a concentration-dependent decrease in MMP2 activity in culture media, acting directly and selectively on MMP2 (not affecting MMP9). The importance of the cyclized structure is demonstrated by the inactivity of the corresponding linear sequence in the same experiment. Compound 2 also decreases cell mobility in a wound-healing scratch assay, and this activity correlates with the measured $\mathrm{K}_{\mathrm{D}}$ of its interaction with proMMP2, supporting a mechanism of action involving the indicted PPI.

The vascular endothelial growth factor (VEGF) is one of the most important factors promoting angiogenesis, the process of formation and proliferation of blood vessels. An- 
giogenesis plays an important role both in physiologic and pathologic situations, like for instance cancer and rheumatoid arthritis [35]. VEGF exerts its proangiogenic activity through the interaction with its transmembrane receptors, which has tyrosine kinase activity. Despite the interest in small-molecule tyrosine kinase inhibitors [36], targeting the extracellular domain of VEGF receptor 1 (VEGFR1) to hamper its interaction with VEGF could constitute an alternative strategy to modulate this proangiogenic system. Based on the X-ray structure of VEGF-VEGFR1 complex, and taking as model the amino acid sequences of VEGF identified as key hot-spots for its interaction with VEGFR1, Pérez de Vega and co-workers designed conformationally constrained peptide analogues for hampering the VEGF-VEGFR1 interaction; therefore, for blocking the cascade of biological events triggered by this protein-protein interaction [37-39]. Different mutagenesis and structural studies permitted the identification of two main hot-spots, at the interaction interface of VEGF with VEGF1, namely fragment $\mathrm{VEGF}_{81-91}$, which is part of a $\beta$-hairpin structure, and fragment $\mathrm{VEGF}_{17-25}$, located at the N-terminal and having $\alpha$-helical conformation. With the aim of mimicking the 3D structure adopted for the VEGF hot-spots native sequences, cyclic constrained 10 to 13-mer peptide derivatives were designed (Figure 1, examples 3-5). The strategy involved the crosslinking of amino acid side-chains keeping unaltered the residues reported as important for the molecular recognition. To mimic the native $\beta$-hairpin of $\mathrm{VEGF}_{81-91}$ fragment, different type of bridges were generated to link together the two strands, in particular hydrocarbon-, disulfide-, and amide-linkers (CO-NH and NH-CO) $[37,38]$. The restriction with the NHCO bridge afforded the best cyclic peptide in the series $\left(\mathrm{IC}_{50}=87.6 \mu \mathrm{M}\right)$. Concerning the second hot-spot, $\mathrm{VEGF}_{17-25}$, and to fix the $\alpha$-helix, amide bridges were formed from the amino acid side-chains of conveniently situated Glu and Lys residues, at relative positions $i$ and $i+4$. Analogues of both VEGF $17-25$ and Vammin $69-80$, the homologue fragment of an antiangiogenic VEGFrelated protein from snake venom, were prepared [39]. Vammin-derived cyclic peptide 4 , having the conformational restriction closer to the $\mathrm{N}$-terminus of the sequence, compared to regioisomeric analogue 5 , exhibits the best $\mathrm{IC}_{50}$ value $(36 \mu \mathrm{M})$.

\subsection{Cyclic Peptides of Natural Origin}

Isolation from natural sources is a complementary technology to feed screening programs for PPI modulation. Plant-derived cyclotides are disulfide-rich cyclic peptides with extraordinary resistance to thermal, chemical, and enzymatic degradation, and good cellpenetrating ability, and therefore, good candidates to modulate intracellular PPIs [40,41]. Engineering the metabolically unstable N-terminal fragment of p53 (Figure 2, labeled in red) into a cyclotide scaffold results in cyclic derivative 6 (MCoTI-I) as an efficient antagonist of the intracellular p53 degradation [42]. This compound is highly stable in human serum, binds to HDM2 protein with low nanomolar affinity, and shows both in vitro and in vivo cytotoxic activity in wild-type p53 cancer cell lines. In LNCaP cells, cyclic peptide 6 activates the p53 tumor suppressor pathway by disrupting the p53-Hdm2 complex and inducing G1/S cell cycle arrest. A number of naturally-occurring cyclopolypeptides of marine origin, like proline-rich derivatives [43], and small Trp-derived peptides (7, Figure 2) [44], also display a broad range of pharmacological activities, including antitumor, antibacterial and antiviral actions. Despite that these marine cyclic peptides could be useful scaffolds for modulating challenging PPIs, to the best of our knowledge there is no information about their specific PPI targets. 


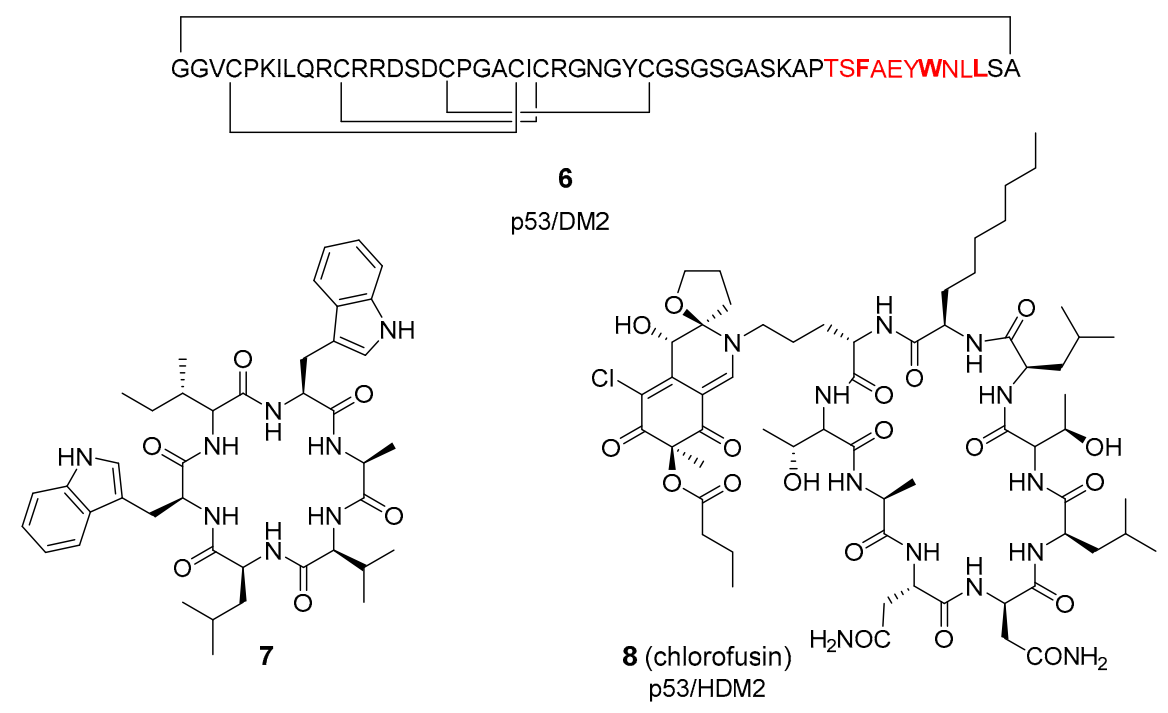

Figure 2. Selected examples of cyclic peptides isolated from natural sources or obtained after modification of naturally-occurring cyclopeptides.

M. Moore's group described the isolation from Microdochium acaespitosum, and ulterior synthesis of the natural cyclopeptide chlorofusin (8, Figure 2) [45]. These cyclic nonapeptides, which bear a chromophore on the Orn side-chain, blocks the p53-MDM2 PPI $\left(\mathrm{IC}_{50}=4.6 \mu \mathrm{M}\right)[46]$, through direct contact with HDM2 protein $\left(\mathrm{K}_{\mathrm{D}}=4.7 \mu \mathrm{M}\right)$, as demonstrated by surface plasmon resonance (SPR) spectroscopy. More recently, a simpler 4-methylphenyl triazolyl derivative at the Orn side-chain was also described to prevent this PPI, but with one order of magnitude lower activity than the natural product [47]. Fortunately, the synthetic intermediates leading to this latter chlorofusin peptide derivative allowed the identification of new non-peptide inhibitors of the p53-MDM2 interaction.

\subsection{Biochemical Approaches to Cyclic Peptides}

Different biochemical technologies have been developed to assist in the generation of cyclic/macrocyclic peptide combinatorial libraries and their evaluation in high-throughput screening (HTS) systems as modulators of PPIs (recently reviewed in [10,48]). These techniques and some selected examples are discussed below, and depicted in Figure 3.

The phage display technique, a process in which large, highly diverse libraries of peptide/protein variants are generated on the phage surface, is a dominant tool in mapping protein-protein contacts and the search for PPI modulators [49,50]. Thus, disulfide bridged cyclic peptides were identified by phage display as the first inhibitors of HIV integrin (IN) and the cellular cofactor lens epithelium-derived growth factor (LEDGF/p75). Synthetic sequences corresponding to the identified peptides, like 9 (Figure 3), block HIV replication in different cell lines, while scramble analogues do not. The results indicate that the Trp residue is crucial for the interaction with LEDGF/p75 protein and suggest that the LEDGF/p75-IN interaction could be important for HIV replication and an emerging therapeutic target [51]. Fibroblast growth factor receptor 1 (FGFR1) is overexpressed in lung and breast cancers and therefore drugs targeting FGF1/FGFR1 PPI could be an alternative to small-molecule tyrosine kinase inhibitors for handling FGFR1-dependent cancers. In this respect, the group of Jacek Otlewski described the selection of cyclic peptides able to disrupt the FGF1/FGFR1 interaction prepared by phage display [52]. The most potent cyclic peptide 10, but not its linear peptide equivalent, is able to inhibit the FGFR1 downstream signaling and the FGF1-induced cell proliferation in cell expressing FGFR1. This peptide could be the starting point to new molecules targeting the FGF1/FGFR1 interaction for fating against FGFR1-overexpressing cancers. 


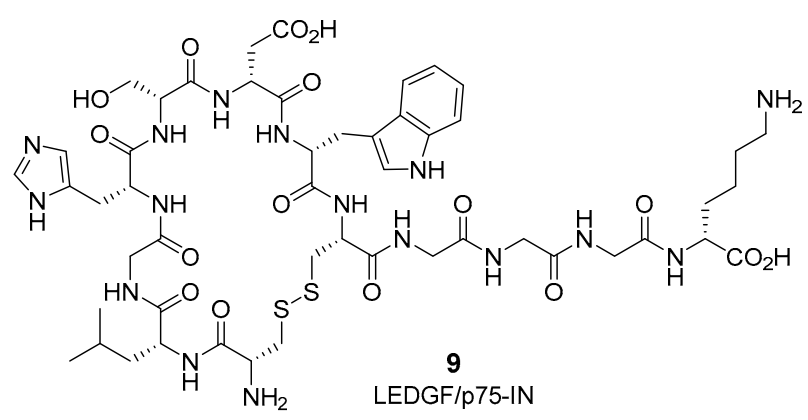

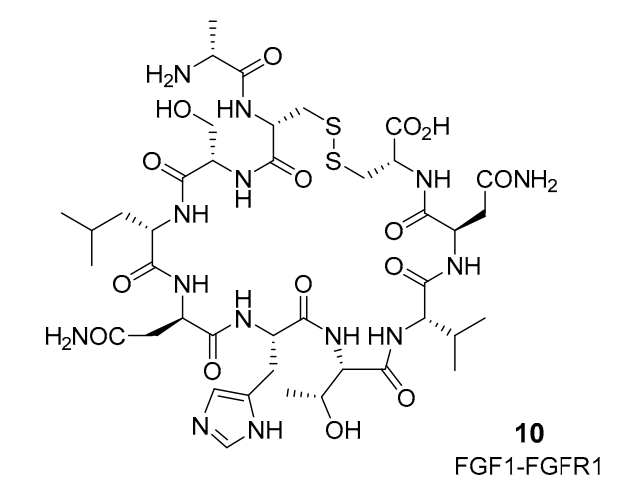

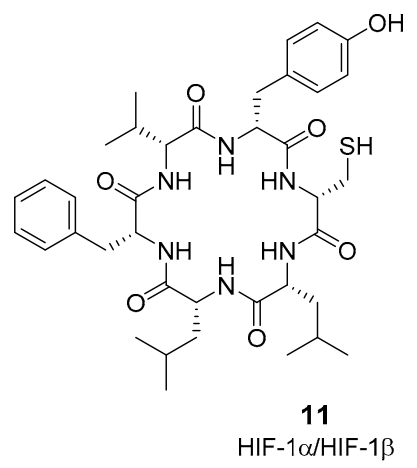

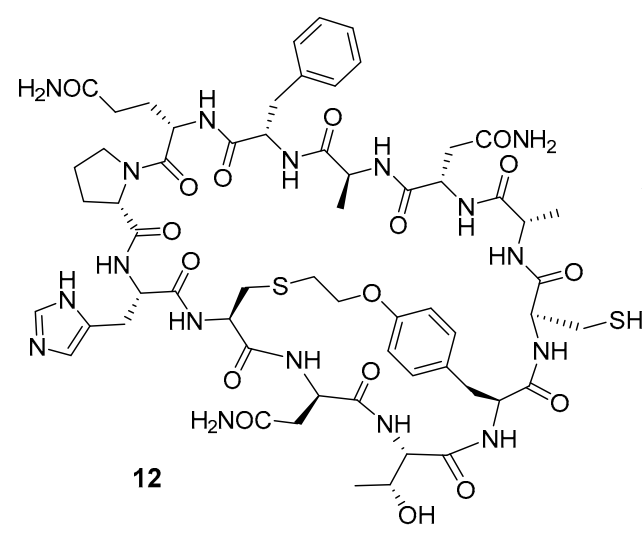

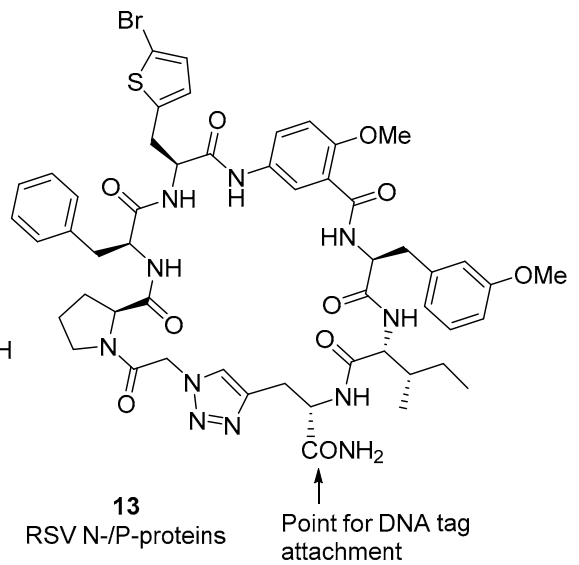

Figure 3. Cyclic/macrocyclic peptides discovered after application of biochemical technologies.

Macrocyclic organopeptide hybrids (MOrPHs), a strategy developed by Rudi Fassan's group, conjugate non-proteinogenic synthetic moieties into genetically encoded peptide frameworks [53]. The method consisted in the incorporation of an N-terminal O-alkynecontaining Tyr residue into intein-fused polypeptides, followed by chemoselective triazol formation with and azide/hydrazide-containing organic moiety. The thioester transient bond at the connection with the intein makes possible the cyclization of the recombinant peptide to organopeptide macrocycle through a hydrazide bond. Another very recent example describes the generation of $10^{5}$ - to $10^{8}$-member libraries constrained through non-reducible thioether bridge [54]. Further screening against different protein-protein interaction, led to the identification of potent peptide macrocycles to disrupt the Keap1/Nrf2 (best component $\mathrm{K}_{\mathrm{D}}: 40 \mathrm{nM}$ ), a PPI associated to the upregulation of cytoprotective enzymes of interest for inflammatory processes, and the interaction between Hedgehog interacting protein (HHIP) and Patched-1 (PTCH1) transmembrane receptor $\left(\mathrm{K}_{\mathrm{D}}: 550 \mathrm{nM}\right)$, of interest for treating various human malignancies [54].

The ribosomal synthesis of cyclic peptides in bacteria is another valuable approach toward big peptide libraries. As representative examples, the head-to-tail cyclohexapeptide 11 (Figure 3), identified from a big library generated using split-intein mediated protein splicing (SICLOPPS) [55], behaves as an inhibitor of the HIF-1 $\alpha / \mathrm{HIF}-1 \beta$ PPI in vitro and prevents HIF-1-mediated hypoxia in cells, altering transcriptional responses to hypoxia [56]. 
Similarly, cyclo-SGWTVVRMY was discovered through the SICLOPPS technology as a disruptor of the dimerization of the C-terminal binding protein transcriptional repressor (CtBP1/CtBP2), involved in epigenetic regulation and in the proliferation and migration of cancer cells [57]. Ribosomal derived peptide sequences can be also macrocyclized through chemoselective reaction between an unnatural amino acid, the $O$-(2-bromoethyl)-tyrosine, and a cysteine residue, which combined with the SICLOPPS strategy allow the preparation of macrocyclic peptides (i.e., compound 12, Figure 3), which could also be of future interest toward PPI inhibitors [58].

Yeast surface display, alone or in combination with phage display, starts to be an approach for the quick identification of protein binders, with only a few examples to express cyclic peptide derivatives nowadays. Thus, genetically encoded libraries generated by using yeast surface display serve to identify cyclic peptides that bind to lysozyme, interleukin-17 (IL-17) and IL-23 [59,60], and help to envisage this technique as a future strategy toward peptide drug leads and inhibitors of relevant PPIs. Another attractive, completely in vitro method for library production is the mRNA display, which allows the insertion of non-natural amino acid residues and peptide cyclization [61,62], though the application to find PPI binders need to be explored yet.

As for small-molecule libraries [63], the incorporation of a DNA sequence during the synthesis of combinatorial peptide libraries constitutes another valuable approach for the production of big library pools, isolation of peptide sequences with high affinity for a given protein, and simple determination of peptide primary structure by sequencing the encoding DNA [64]. In this sense, the group of Z. Zhu described the synthesis and biological evaluation of a DNA-encoded macrocyclic peptide library with $2.4 \times 10^{12}$ components, by combining proteinogenic and non-proteinogenic amino acid residues [65]. This library was tested as inhibitors of the PPI between N- and P-proteins of the respiratory syncytial virus (RSV), important for replication and considered an innovative target to fight against the infection caused by this virus. After identification of the most interesting sequence binders, selected cyclic peptides were resynthesized without the DNA tag, using solid-phase methodologies, and reevaluated. Compound 13 (Figure 3) is one of the best confirmed hits, with good ability to bind to N-protein (affinity selection-mass spectrometry assay) and to disrupt the interaction of RSV N- and P-proteins (pIC50 6.98, time-resolved fluorescent resonance energy transfer assay) [65]. The activity is much higher for this cyclic peptide than for the corresponding linear analogue, suggesting that the reduced mobility of $\mathbf{1 3}$ could result in lower entropic cost for binding.

\subsection{Synthetic Strategies to Cyclic Peptide Libraries}

Regarding chemical approaches, in recent years, there is a continuous development of strategies for the preparation of cyclic peptides, their diversification, and their presentation on tagged-resins, all with the main objective of allowing a rapid identification of active peptide derivatives. In addition, there is an important progress in different stratagems for obtaining macrocyclic products, which comprise a peptide sequence and a more or less extensive, non-peptide organic region that could serve either to modulate the activity of the peptide or to facilitate the macrocyclization process [66].

The group of Dehua Pei designed and synthesized a large combinatorial library of bicyclic peptides $\left(6.6 \times 10^{13}\right.$ components) and screened it against TNF $\alpha / \mathrm{TNF} \alpha \mathrm{R}$ PPI [67]. The format of the library is one bead-two compound (OBTC), each bead containing a unique bicyclic peptide and the corresponding linear analogue, as encoding tag for facilitating hit identification. This library, combining proteinogenic and unnatural amino acids, contains a planar organic scaffold, trimesic acid, to foster an overall planar shape of the bicyclic peptide for facilitating the interaction with flat protein surfaces. One component of this library, named anticachexin C1 (14, Figure 4), is a potent non-protein TNF $\alpha$ inhibitor $\left(\mathrm{K}_{\mathrm{D}}=0.45 \mu \mathrm{M}\right)$ [67]. 

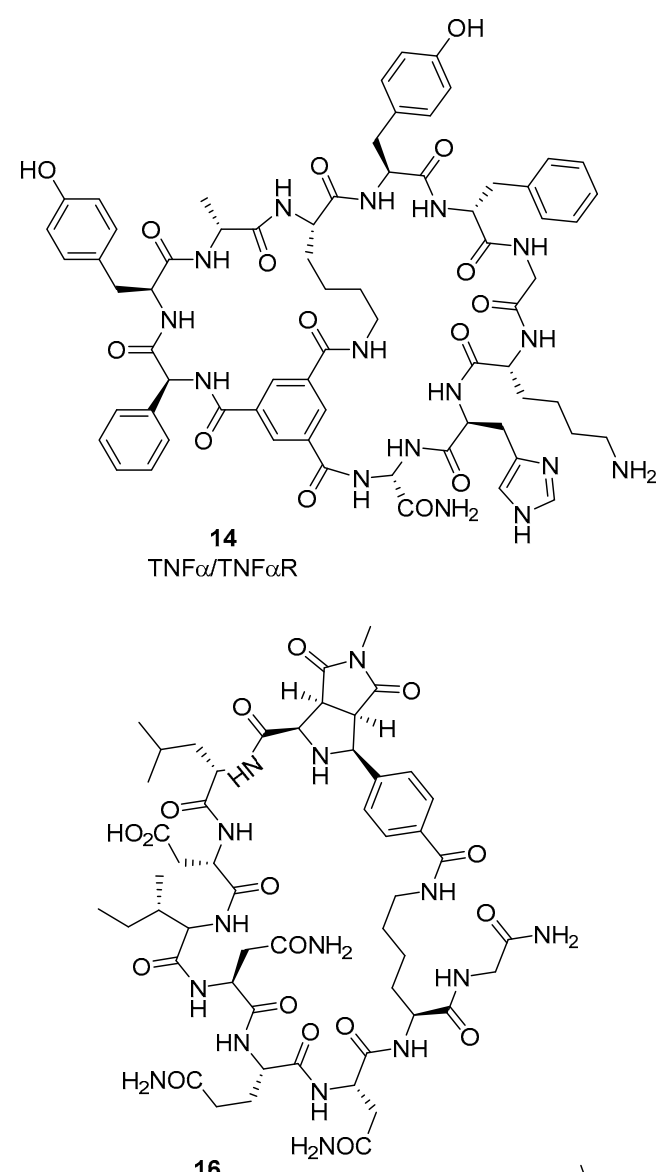

16
iNOS/SPSB2<smiles>CC(C)CC(NC(=O)C(Cc1c[nH]c2ccccc12)NC(=O)C(NC(=O)C(NC(=O)C(NC(=O)C(C)C)C(C)C)C(C)C)C(C)C)C(C(C)C)C(C)C</smiles>

15 (Lugdunin) Antimicrobial activity

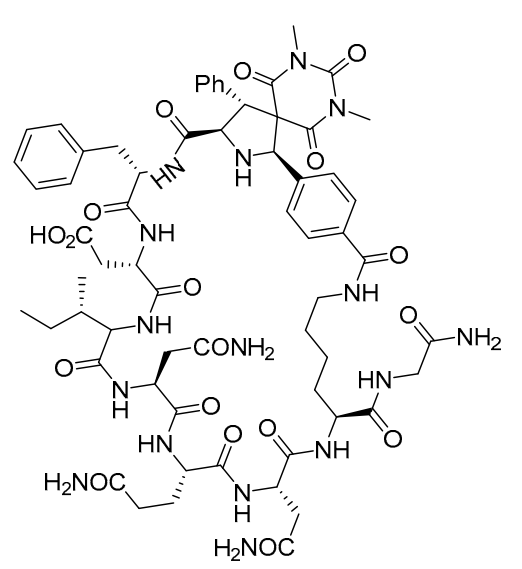

17 $\stackrel{17}{\text { NOS/SPSB2 }}$

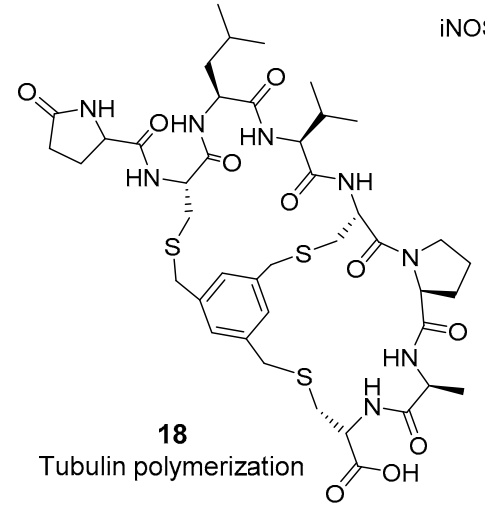

Figure 4. Selected components of totally synthetic macrocyclic peptide libraries with PPI disrupting properties.

New methods toward cyclic peptides formed via linkage between amino acid sidechain functional groups and reactive organic moieties have recently been reported. Thus, Luo et al. described the synthesis of 1,4-di-nitroimidazole-derived peptides formed by electrophilic bioconjugation of Cys and/or Lys side-chains and 4-nitroimidazol derivatives [68]. The method is chemoselective, controllable under different reaction conditions, allowing easy access to macrocyclic peptide with complex ring structures, and selective protein modification. Another relevant cyclization method was described by the group of Xuechen Li [69], which prepares isoindole-bridged cyclic peptides through simultaneous reaction of the amino group of Lys side-chain (or the $\mathrm{N}$-terminal $\mathrm{NH}_{2}$ ) and the thiol group of Cys side-chains with orthophthalaldehyde (OPA). This transformation takes place in an efficient manner in aqueous buffers and can also be combined with other cyclization methods, like native chemical ligation. In addition, OPA-derived cyclic peptides can react 
with $\mathrm{N}$-maleimide derivatives, containing biomolecules or fluorophore probes for further bioconjugation.

The use of multicomponent reactions (MCRs) to facilitate the macrocyclization of peptides is also being widely applied, as described in a recent comprehensive review [70]. In this respect, Dömling et al. described a library of indole-based macrocyclic p53MDM2 antagonists, using an Ugi macrocyclization from $12 \alpha$ - $\omega$-amino acids and indole-3carboxaldehydes [71]. On the other hand, the generation of imine intermediates for further diversification also merits special attention. Thus, the group of Phil Baran described the imino macrocyclization in aqueous media of non-ribosomal peptides [72]. Stating from linear peptide aldehydes with certain propensity to autocyclize to the corresponding imine derivatives, they drive imine trapping through intermolecular Strecker protocols and reductive amination procedures, or intramolecular entrapping using appropriate $\mathrm{N}$-terminal amino acids (tetrahydro- $\beta$-carbolines from Trptetrahydro- $1 \mathrm{H}$-imidazo [4,5-c]pyridines from His, and thiazolidine and oxazolidine from Cys and Thr). The described procedures accept a wide variety of linear peptides (5 to 10 amino acid residues), which can include functionalized side-chain residues (Arg, Asp, Gln, Cys(StBu), Lys, Tyr). The cyclization process can be modulated through the incorporation of N-Me groups and non-natural D-residues. This versatile procedure was applied to the preparation of different naturally-occurring macrocyclic peptides and analogues, like lugdunin (15, Figure 4), an antimicrobial peptide with activity against Gram-positive bacteria (i.e., Staphylococcus aureus) [72]. Another approach that used cyclic imine peptides as key intermediates for further molecular expansion is the PepNats strategy, recently described by the group of Herbert Waldmann [73]. In this case, for exploratory studies, all initial linear peptides incorporating a Gly residue at $\mathrm{N}$-terminal, and a Lys(Mtt) residue at n-1 position, which upon orthogonal Mtt removal and coupling of $N^{\varepsilon}$-Lys with 4-formylbenzoic acid affords the aldehyde group for the Schiff base formation. Trapping the imine moiety with different dipolarophiles (1,3-dipolar cycloaddition), through previous azometine ylide generation, afforded different natural product-inspired cycloadducts. The entire process can be conducted on solid-phase and is versatile regarding peptide sequence, enabling the stereoselective preparation of libraries of diverse heterocycle-containing peptide macrocycles. NMR studies demonstrated that the conformational preferences in solution of these PepNats are dependent on the configuration and structure of the heterocycle, factors that also impact their activities as PPI modulators. Inducible nitric oxide synthase (iNOS) is a key mediator of immune activation and inflammation, with overexpression or dysregulation in pathologies like osteoarthritis, sepsis, cancer, neurodegeneration, and various types of pain. The lifespan of iNOS is regulated by the proteasome after ubiquitination by the E3 ubiquitin ligase complex, being SPSB2 one of the adaptor proteins. In cancer, production of NO could contribute to kill tumor cells, therefore, disruptors of the SPSB2-iNOS interaction could led to alternative antitumor agents. Application of the PepNat strategy to the modulation of the iNOS-SPSB2 PPI led to the discovery of di-pyrrolidine and pyrrolidinyl-spirobarbiturate macrocyclic peptides 16 and 17 (Figure 4), with low nanomolar potencies in the binding tor SPSB2 $\left(\mathrm{IC}_{50}=10\right.$ and $3.8 \mathrm{nM}$, respectively). Therefore, the imine-based synthetic methodologies open the opportunity to apply imine-derived macrocyclic peptides in the search for modulators of other therapeutically relevant PPIs.

Other efforts have been directed to complex bicyclic peptide structures. Thus, the group of Craig A. Hutton reported a small library of bicyclic peptide derivatives as analogues of celogentin $C$, a natural product that inhibits tubulin polymerization. They ideated the formation of the bicyclic core by using a tris-(bromomethyl)benzene moiety and three Cys residues conveniently positioned within the linear peptide precursor. SAR studies show that Leu3, Val4, and Pro6 are essential residues for activity. In the most active compound, $18\left(\mathrm{IC}_{50}=2.2 \mu \mathrm{M}\right)$, the Arg7 residue in celogentin $\mathrm{C}$ is replaced by Ala (Figure 4). Macrocyclic peptide 18 shows enhanced activity over the antitumor drug vinblastine [74]. Using a similar strategy, Timmermann's group discovered, via HTS of partially randomized libraries, new bicyclic RGD peptides with nanomolar affinity, and 
selectivity for integrin $\alpha v \beta 3$, as antitumor and diagnosis agents [75]. The formation of the bicyclic peptide derivatives was carried out by reaction L- or D-Cys(c) residue with 1,3,5-tris(bromomethyl)benzene, combining the universal integrin-binding sequence ArgGly-Asp (RGD) in one loop, and a randomized sequence XXX ( $X=$ one of 18 canonical L-amino acids) in the second loop.

\subsection{Cell Penetrating Cyclic Peptides}

To increase the permeability of these normally big molecules, the conjugation with cellpenetrating peptide (CPP) and the facilitation of active transport have been studied [20,47]. Two main ways have been described for the integration of cyclic peptide cargos with cyclic $\mathrm{CPPs}$, the conjugation through different types of linker and the generation of fused bicyclic peptides [76].

Within the first strategy, the group of Dehua Pei described the conjugation of a cyclic peptide inhibitor of Kelch-like ECH-associated protein 1 (Keap1)-nuclear factor erythroid-2 (Nrf2) PPI and a cyclic poly-Arg CPP, covalently linked through flexible connectors [77]. Bicyclic peptide 19 (Figure 5) retains Keap1-binding affinity $\left(\mathrm{IC}_{50}=48 \mathrm{nM}\right)$, is quite stable against proteolytic degradation, penetrates mammalian cell membranes, and activates gene transcription mediated by Nrf2. A similar, recent work affords important SAR on the structural requirements of the KEAP1-NRF2 PPI, and the conjugation of NRF2derived cyclic peptides to different CPPs increases the in vitro activity compared to their unconjugated analogues [78].
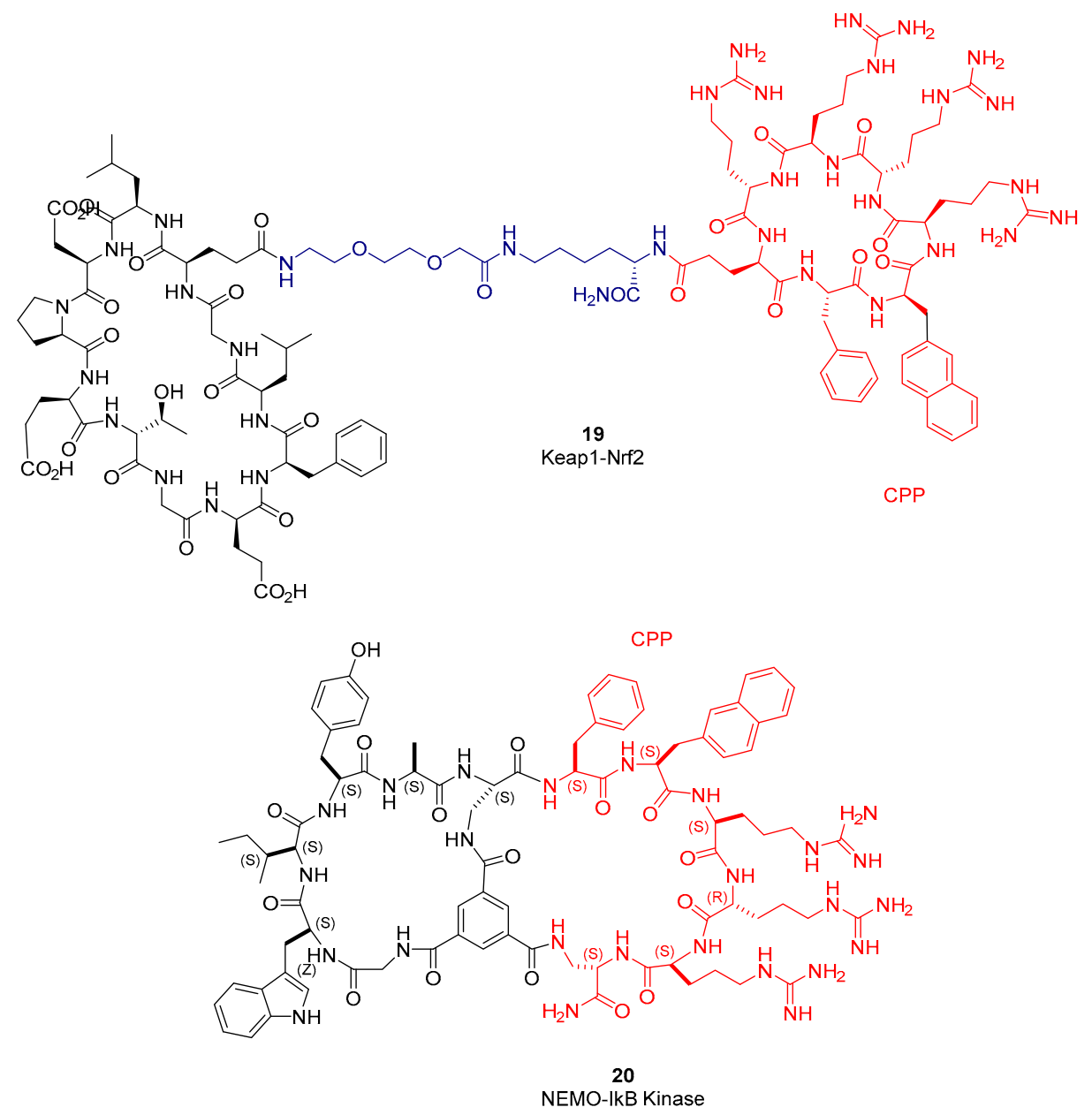

Figure 5. Selected examples of cell-penetrating peptide (CPP)-cyclic peptide conjugates and bicyclicmerged peptides. 
As a proof-of-concept to enhance the limited cell permeability of stapled peptides, some impermeable peptidyl inhibitors of MDM2/p53 and $\beta$-catenin/TCF PPIs were conjugated with cyclic CPPs [79]. This approach ensured peptide conjugates with antiproliferative activity, decreasing the viability of SJSA-1 and SW480 tumor cell cultures.

In the second approach, Pei's group merges randomized cyclic hexapeptides, composed of natural and non-proteinogenic residues, with diverse CPP sequences to generate a large library of bicyclic peptides [80]. This library was checked for inhibition of the NF- $\kappa B$ essential modulator (NEMO)-I $\kappa B$ kinase interaction. They identify cell-permeable bicyclic peptide 20 (Figure 5) as the most potent binder of NEMO protein reported to date $\left(\mathrm{IC}_{50}=1 \mu \mathrm{M}\right)$. This bicyclic peptide inhibits de NF-kB signaling and shows anticancer activity in A2780 and CP70 tumor cell lines [80].

Another prominent strategy for inhibitors of intracellular PPIs is grafted peptides, combining in a unique cyclic molecule a protein epitope and an Arg-rich peptide. As an example, the helical p53 epitope embedded together with helical peptides containing up to six Arg residues, led to inhibitors of the p53-HDM2 interaction [81]. The best peptide, shows high binding affinity for HDM2, cell membrane penetration, and antiproliferative activity in vitro (HCT116 and LnCap cells), suggesting a p53-dependent in vitro activity.

All these approaches could be applicable to the discovery of cell-permeable peptides against other intracellular PPI targets. In addition, the identification of new CPPs is pursued to discover shuttling vectors for peptide cargo transportation. In this respect, SARS-CoV2 virus, the etiological causative of COVID-19, needs to infect animals or humans to replicate, as other viruses, and as a consequence it should have CCPs in its proteome. A recent computational study analyzed the SARS-CoV- 2 proteins and identified $>300$ sequences with potential CPP ability and involved in important processes like protein-protein interactions and homo/hetero-oligomer stabilization [82]. Further filtering allowed the identification of peptide sequences with no antigenic or allergenic properties and resistant to main groups of proteases. Some Cys-rich CPPs from helicase (NSP13), which could fold into cyclic peptides in endosomes, have also been envisaged. All these sequences could constitute the starting point for the discovery of innovative CPPs, which could have biological activity by themselves, or serve as transporters to permeate other bioactive peptides into the cell.

\subsection{Photoswitchable Cyclic Peptides}

Photoswitchable peptides PPI inhibitors are molecules that only adopt their active/inhibitory conformation when exposed to light at certain wavelengths. Olalla Vazquez and Lea Albert recently summarized the state-of-the-art on photoswitchable peptides for the control of biological functions [83].

The group of Ernest Giralt described a series of 20-mer azobenzene-crosslinked peptides to fine-tune their interaction with $\beta$-adaptin 2 , a key protein involved in clathrinmediated endocytosis through its interaction with $\beta$-arrestin [84]. This study concludes that the helix stabilization by the photoswitchable moiety or by incorporation of Aib residues is not a requirement for good inhibitors. The best peptide in this series, 21 (Figure 6), has $\mathrm{i}$, $\mathrm{i}+7$ crosslinking and shows a $\mathrm{Ki}^{\text {off }} / \mathrm{Ki}^{\text {on }}>10$ (micromolar range). The same group defined new photoswitchable peptides for interfering in Bcl-xL-Bak and MDM2-p53 PPIs [85], involved in apoptosis. In the last case, they prepare photoswitchable retro-enantio p53derived peptides, with partial $\alpha$-helical structure. Peptide 22 (Figure 6) interact with MDM2, showing low activity at the dark and a 10-fold strong binding after UV light exposure (380 $\mathrm{nm}$ illumination).

A different approach has been described by the Urlich's group [86], using a photoswitchable diarylethene moiety to stabilize the $\beta$-hairpin secondary structure of the natural membranolytic peptide gramicidin S (23, Figure 6). The library of peptides was tested for their antibacterial and antitumor activity. In general, these peptides show low hemolytic cytotoxicity, especially for hydroxyleucine-containing derivatives. Compound $\mathbf{2 3}$ shows selective antimicrobial activity against Gram+ bacteria and cytotoxicity in different cancer cell lines, and was active in doxorubicin-resistant tumor cells [86]. A small library of related 
photoswitchable analogues of gramicidin $\mathrm{S}$ were studied for their embryotoxicity in the two photoforms, revealing higher toxicity for ring-open isomers [87].

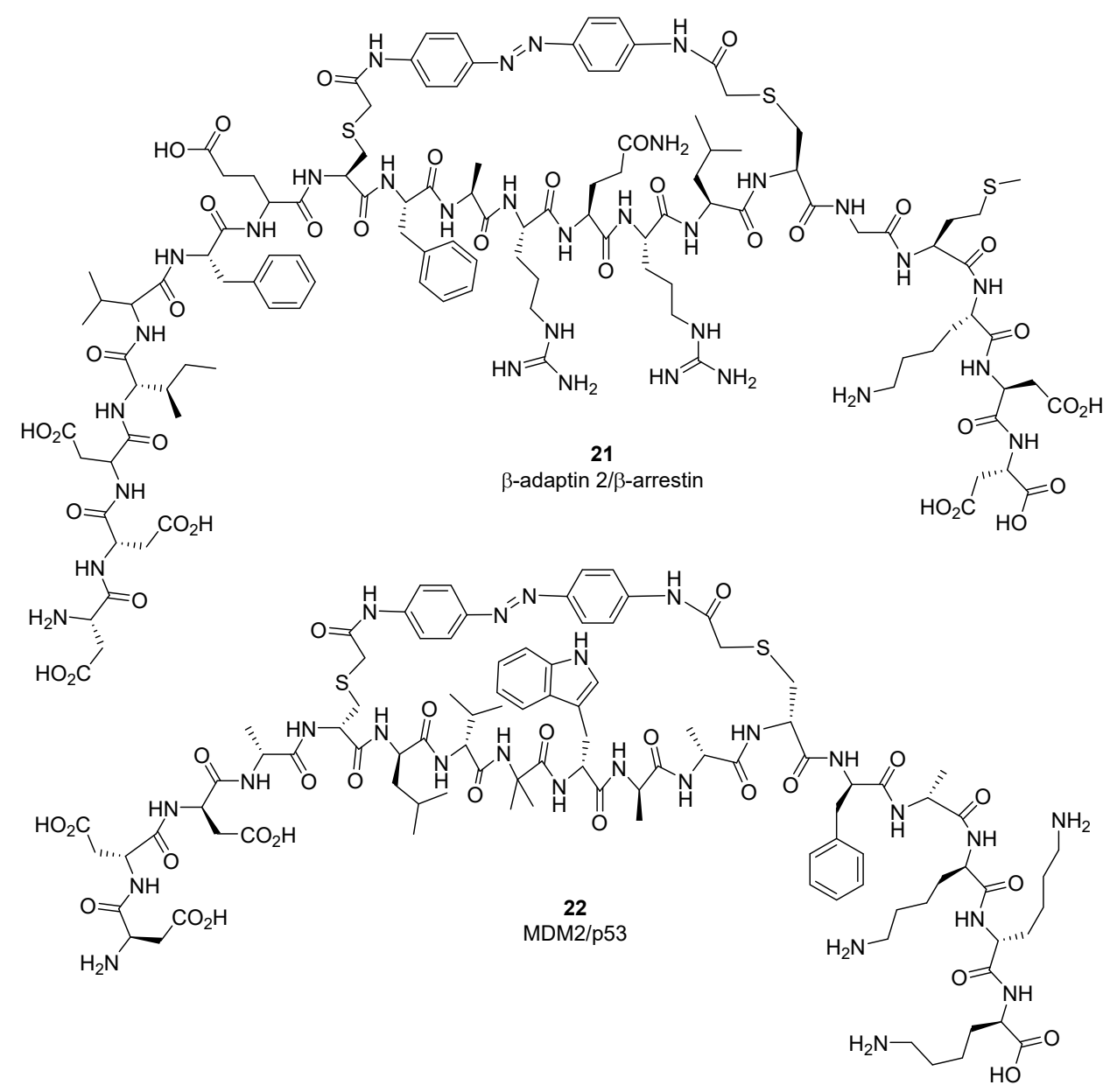

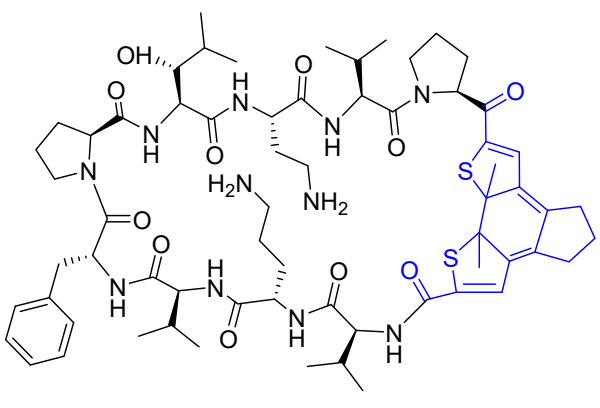

23 "ring-closed"

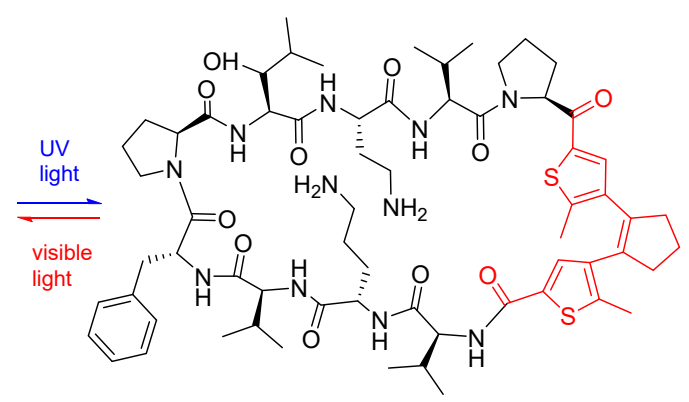

23 "ring-open"

Figure 6. Selected examples of photoswitchable cyclic peptides.

\section{7. $\beta$-Amino Acid-and Peptoid-Containing Cyclic Peptides}

Other strategy for constructing peptide-based PPI inhibitors is the modification of the backbone structure, by extension (incorporation $\beta$-amino acid) or by shift of side-chains to nitrogen atoms (peptoids). Oligomers that contain only $\beta$-amino acids ( $\beta$-peptides) or both natural $\alpha$-amino acids and unnatural $\beta$-amino acids ( $\alpha / \beta$-peptides) normally display high resistance to proteolytic degradation [88], can mimic natural $\alpha$-helices, and are capable of modulate helix-mediated PPIs [89]. The synthesis of such peptides can be considered practicable, based on standard SPPS protocols, and is facilitated by a number of commercially available $\beta$-amino acids, which also could be obtained through quite simple synthetic methods [90]. Due to their high conformational stability, $\beta$-peptides 
are shorter than $\alpha$-peptides but can achieve a similar degree of folding. The use of this type of backbone-modified peptides as inhibitors of PPIs has previously been revised [91], with important examples targeting Bcl-2-2BH3 domain [89,92], VEGF-VEGFR1 [93], and p53-MDM2 [94], among others. As a recent example of $\alpha / \beta$-hybrid peptides, the group of Douglas Fairlie reported a few peptides, based on a stapled Bim BH3 structure, with enhanced $\alpha$-helix stability (CD), high resistance to proteolytic degradation $(>100)$, and comparable ability to neutralize anti-apoptotic protein function, in a cellular milieu, to the parent stapled $\alpha$-peptide [95].

Other particular promising class of foldamers is the peptoid structure, composed of Nsubstituted glycine peptidomimetics. In peptoids side-chains are moved from the $\alpha$-carbon to backbone amide nitrogen. This backbone modification provides high protease resistance, although the positioning of key interacting residues in the right place is sometimes a challenge. Peptoid-based inhibitors, can be exemplified by PPI inhibitors of VEGF-VEGFR [96], apoptotic protease-activating factor 1 (Apaf-1) [97], and skp2-p300 [98]. Thus, macrocyclic peptoid 24 (Figure 7) binds to Skp2 protein and interferes with the Skp2/p300 interaction, a PPI with potential to develop new anticancer drugs. Skp2 mediates the degradation of cell cycle proteins and suppresses p53-mediated apoptosis, competing with p53 for binding to p300 protein. Therefore, macropeptoid $\mathbf{2 4}$ can be a chemical probe to define the role of SK2 in tumorigenesis.
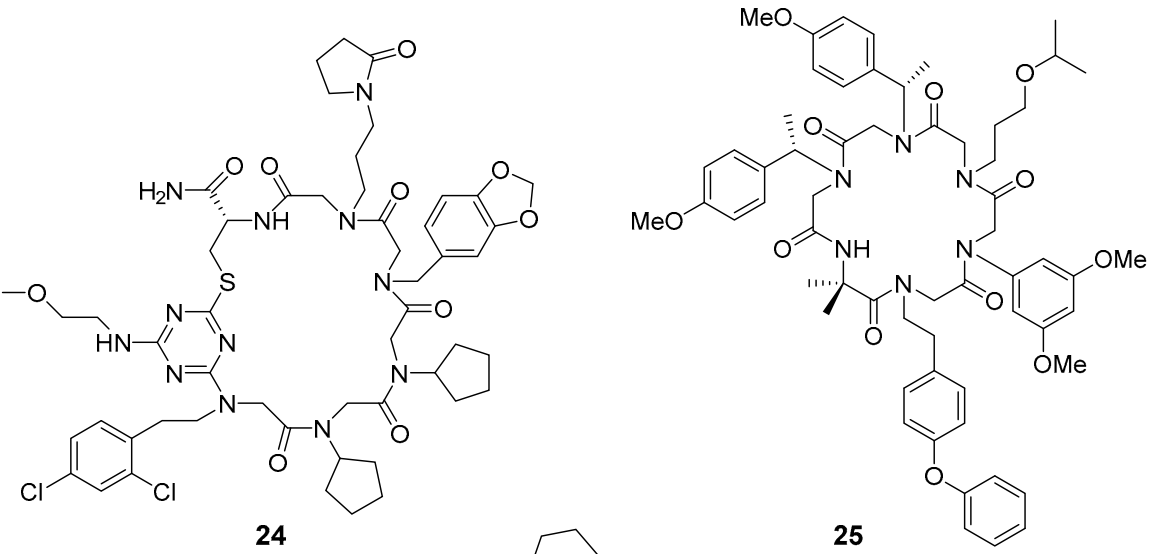

skp2-p300

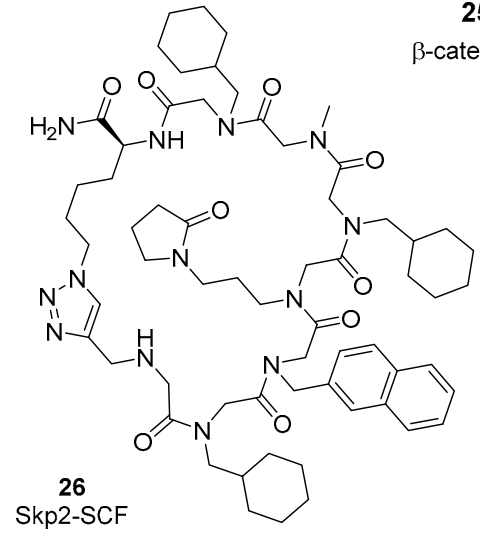

catenin:TCF

Figure 7. Peptoid-based inhibitors of PPIs.

Early studies in silico demonstrate how computational tools, using the reported Rosetta suite of protein design algorithms [99], can facilitate the design of macrocyclic peptoid-peptide hybrids. As an example, peptoid 25 (Figure 7) is able to bind to a pocket in $\beta$-catenin, involved in the association with T-cell factor (TCF), thus disrupting the $\beta$-cateninTCF interaction [100]. In prostate cell lines, macrocycle 25 displays potent antiproliferative activity, inhibiting both the Wnt- and AR-signaling pathways. This compound also shows in vivo activity in a zebrafish model. 
The group of Hyun-Suk Lim described recently the design and preparation DNAencoded library (one-bead one-compound format) of cyclic peptoids ( $>11$ million molecules). This library was screened for binding affinity to S-phase kinase-associated protein 2 (Skp2), an adaptor protein involved in cell-cycle progression, senescence, and metabolism. Fluorescence anisotropy assays defined five hit beads, among them, cyclic peptoid 26 (Figure 7) that shows high affinity for Skp2 $\left(\mathrm{K}_{\mathrm{D}}=7.51 \mu \mathrm{M}\right)$, better than those obtained for the all $\mathrm{N}$-methyl analogue and its linear peptoid counterpart [101]. This petoid could be of interest as disruptor of the Skp, Cullin, F-box containing (SCF)-Skp2 complex formation, which has an important role in ubiquitination processes of cell-cycle proteins. Finally, the incorporation of $\mathrm{N}$-methylglycine (sarcosine) in transmembrane peptides for the modulation of membrane PPIs has also been studied [102].

\section{Conclusions and Perspectives}

The advantages of cyclic peptides over linear ones, mainly better stability and improved control of the conformational space, has stimulated the interest of numerous research groups in this type of compounds. Due to their high size, compared to smallmolecules, cyclic and macrocyclic peptides represent a strategic source in the search for protein-protein interaction (PPI) modulators. In this short review we have tried to illustrate main methods to access this type of molecules, selecting some representative examples of modulators for therapeutically relevant PPIs.

Main advances in computational methods are addressing the complex design of new cyclic peptides, while phage or yeast expression gives rise to large collections of compounds for exploring different PPIs. Organic synthesis is not far behind, guided by the advancement of solid-phase methodologies (SPPS), allocating the preparation of diverse, complex cyclic/macrocyclic peptide libraries. It is also worth highlighting the combination of SPPS with efficient reactions, such as multicomponent processes (mainly those based on cyclic imines), for exploring new chemical space to develop macrocyclic peptides. The cellular permeability of this type of molecules is also being successfully addressed, primarily through the incorporation of cell penetrating peptides CPP), linked either through spacers or condensed into bicyclic structures. The incorporation/combination of $\beta$-amino acids and peptoids is also contributing to the expansion of chemical architectures and to obtain metabolically stable systems.

In the time of the dreadful pandemic, cyclic and macrocyclic peptides could also play an important role in the search for antiviral agents. It is now fairly well established that the virus spike protein interacts with ACE2 and neuropilin-1 receptors through protein-protein interactions [103-105]. Similarly, the main protease (Mpro) of SARS-CoV-2, the causative etiological agent of COVID-19, is a transient homodimer indispensable for processing virus essential proteins [106]. Investigation is open for peptides and small organic molecules capable of destabilizing the homodimerization and, therefore, for preventing the activity of Mpro.

It is estimated that there could be 650,000 disease-relevant PPIs, but most of them remain unexplored already. Hence, cyclic and macrocyclic peptides can have tremendous potential. Inspiration and creativity of researchers working in this field, theoretical and synthetic chemists, biochemists, molecular biologists, bioinformatics, will contribute to the discovery of new PPIs and to illuminate the generation of different complex peptide structures for disrupting/stabilizing them. They could be novel biological/chemical tools and perhaps new future drugs, hence involved scientists have a long road ahead.

Author Contributions: Conceptualization, R.G.-M.; writing-original draft preparation, R.G.-M., M.Á.B., and M.J.P.d.V.; writing—review and editing, R.G.-M.; funding acquisition, R.G.-M. All authors have read and agreed to the published version of the manuscript.

Funding: This research was funded by the Spanish Ministerio de Ciencia y Universidades (MICYUFEDER, RTI2018-097189-C2-2 to R.G.-M.), and the Spanish National Research Council (CSIC, 201980E030 to R.G.M.). 
Conflicts of Interest: The authors declare no conflict of interest.

\section{References}

1. Scott, D.E.; Bayly, A.R.; Abell, C.; Skidmore, J. Small molecules, big targets: Drug discovery faces the protein-protein interaction challenge. Nat. Rev. Drug Discov. 2016, 15, 533-550. [CrossRef] [PubMed]

2. Skwarczynska, M.; Ottmann, C. Protein-protein interactions as drug targets. Future Med. Chem. 2015, 7, 2195-2219. [CrossRef] [PubMed]

3. Ghadie, M.A.; Coulombe-Huntington, J.; Xia, Y. Interactome evolution: Insights from genome-wide analyses of protein-protein interactions. Curr. Opin. Struct. Biol. 2018, 50, 42-48. [CrossRef] [PubMed]

4. Stumpf, M.P.H.; Thorne, T.; de Silva, E.; Stewart, R.; An, H.J.; Lappe, M.; Wiuf, C. Estimating the size of the human interactome. Proc. Natl. Acad. Sci. USA 2008, 105, 6959-6964. [CrossRef] [PubMed]

5. Fuller, J.C.; Burgoyne, N.J.; Jackson, R.M. Predicting druggable binding sites at the protein-protein interface. Drug Discov. Today 2009, 14, 155-161. [CrossRef]

6. Li, H.; Kasam, V.; Tautermann, C.S.; Seeliger, D.; Vaidehi, N. Computational method to identify druggable binding sites that target protein-protein interactions. J. Chem. Inf. Model. 2014, 54, 1391-1400. [CrossRef] [PubMed]

7. Nevola, L.; Giralt, E. Modulating protein-protein interactions: The potential of peptides. Chem. Commun. 2015, 51, 3302-3315. [CrossRef]

8. Vinogradov, A.A.; Yin, Y.; Suga, H. Macrocyclic peptides as drug candidates: Recent progress and remaining challenges. J. Am. Chem. Soc. 2019, 141, 4167-4181. [CrossRef]

9. Cardote, T.A.F.; Ciulli, A. Cyclic and macrocyclic peptides as chemical tools to recognise protein surfaces and probe proteinprotein interactions. ChemMedChem 2016, 11, 787-794. [CrossRef]

10. Dougherty, P.G.; Qian, Z.; Pei, D. Macrocycles as protein-protein interaction inhibitors. Biochem. J. 2017, 474, 1109-1125. [CrossRef]

11. Bhat, A.; Roberts, L.R.; Dwyer, J.J. Lead discovery and optimization strategies for peptide macrocycles. Eur. J. Med. Chem. 2015, 94, 471-479. [CrossRef] [PubMed]

12. Doak, B.C.; Zheng, J.; Dobritzsch, D.; Kihlberg, J. How beyond rule of 5 drugs and clinical candidates bind to their targets. J. Med. Chem. 2015, 59, 2312-2327. [CrossRef] [PubMed]

13. Villar, E.A.; Beglov, D.; Chennamadhavuni, S.; Porco, J.A., Jr.; Kozakov, D.; Vajda, S.; Whitty, A. How proteins bind macrocycles. Nat. Chem. Biol. 2014, 10, 723-731. [CrossRef] [PubMed]

14. Passioura, T.; Katoh, T.; Goto, Y.; Suga, H. Selection-based discovery of druglike macrocyclic peptides. Annu. Rev. Biochem. 2014, 83, 727-752. [CrossRef]

15. Pelay-Gimeno, M.; Glas, A.; Koch, O.; Grossmann, T.N. Structure-based design of inhibitors of pProtein-protein interactions: Mimicking peptide binding epitopes. Angew. Chem. Int. Ed. Engl. 2015, 54, 8896-8927. [CrossRef]

16. Giordanetto, F.; Kihlberg, J. Macrocyclic drugs and clinical candidates: What can medicinal chemists learn from their properties? J. Med. Chem. 2013, 57, 278-295. [CrossRef]

17. Zorzi, A.; Deyle, K.; Heinis, C. Cyclic peptide therapeutics: Past, present and future. Curr. Opin. Chem. Biol. 2017, 38, 24-29. [CrossRef]

18. Jebrail, M.J.; Ng, A.H.C.; Rai, V.; Hili, R.; Yudin, A.K.; Wheeler, A.R. Synchronized synthesis of peptide-based macrocycles by digital microfluidics. Angew. Chem. Int. Ed. 2010, 49, 8625-8629. [CrossRef]

19. Failli, A.; Immer, H.; Götz, M. The synthesis of cyclic peptides by the four component condensation (4 CC). Can. J. Chem. 1979, 57, 3257-3261. [CrossRef]

20. Itoh, H.; Inoue, M. Full solid-phase total synthesis of macrocyclic natural peptides using four-dimensionally orthogonal protective groups. Org. Biomol. Chem. 2019, 17, 6519-6527. [CrossRef]

21. Dougherty, P.G.; Sahni, A.; Pei, D. Understanding cell penetration of cyclic peptides. Chem Rev. 2019, 119, 10241-10287. [CrossRef] [PubMed]

22. Ali, A.M.; Atmaj, J.; Van Oosterwijk, N.; Groves, M.R.; Domling, A. Stapled peptides inhibitors: A new window for target drug discovery. Comput. Struct. Biotechnol. J. 2019, 17, 263-281. [CrossRef] [PubMed]

23. Moiola, M.; Memeo, M.G.; Quadrelli, P. Stapled peptides-a useful improvement for peptide-based drugs. Molecules 2019, $24,3654$. [CrossRef] [PubMed]

24. Migon, D.; Neubauer, D.; Kamysz, W.; Migon, D. Hydrocarbon stapled antimicrobial peptides. Protein J. 2018, 37, 2-12. [CrossRef] [PubMed]

25. Iyer, V.V. A Review of Stapled peptides and small molecules to inhibit protein-protein interactions in cancer. Curr. Med. Chem. 2016, 23, 3025-3043. [CrossRef]

26. Tan, Y.S.; Lane, D.P.; Verma, C.S. Stapled peptide design: Principles and roles of computation. Drug Discov. Today 2016, 21, 1642-1653. [CrossRef]

27. Cromm, P.M.; Spiegel, J.; Grossmann, T.N. Hydrocarbon stapled peptides as modulators of biological function. ACS Chem. Biol. 2015, 10, 1362-1375. [CrossRef]

28. Foster, A.D.; Ingram, J.D.; Leitch, E.K.; Lennard, K.R.; Osher, E.L.; Tavassoli, A. Methods for the creation of cyclic Peptide libraries for use in lead discovery. J. Biomol. Screen. 2015, 20, 563-576. [CrossRef] 
29. Gao, M.; Cheng, K.; Yin, H. Targeting protein-protein iInterfaces using macrocyclic peptides. Peptide Sci. 2015, $104,310-316$. [CrossRef]

30. McHugh, S.M.; Rogers, J.R.; Solomon, S.A.; Yu, H.; Lin, Y.-S. Computational methods to design cyclic peptides. Curr. Opin. Chem. Biol. 2016, 34, 95-102. [CrossRef]

31. Duffy, F.J.; Devocelle, M.; Shields, D.C. Computational approaches to developing short cyclic peptide modulators of proteinprotein interactions. Meth. Mol. Biol. 2015, 1268, 241-271. [CrossRef]

32. Krüger, D.M.; Glas, A.; Bier, D.; Pospiech, N.; Wallraven, K.; Dietrich, L.; Ottmann, C.; Koch, O.; Hennig, S.; Grossmann, T. Structure-based design of non-natural macrocyclic peptides that inhibit protein-protein interactions. J. Med. Chem. 2017, 60, 8982-8988. [CrossRef] [PubMed]

33. Nefla, M.; Sudre, L.; Denat, G.; Priam, S.; Andre-Leroux, G.; Berenbaum, F.; Jacques, C. The pro-inflammatory cytokine 14-3-3 $\varepsilon$ is a ligand of CD13 in cartilage. J. Cell Sci. 2015, 128, 3250-3262. [CrossRef] [PubMed]

34. Sarkar, P.; Li, Z.; Ren, W.; Wang, S.; Shao, S.; Sun, J.; Ren, X.; Perkins, N.G.; Guo, Z.; Chang, C.-E.A.; et al. Inhibiting matrix metalloproteinase-2 activation by perturbing protein-protein interactions using a cyclic peptide. J. Med. Chem. 2020, 63, 6979-6990. [CrossRef] [PubMed]

35. Aguilar-Cazares, D.; Chavez-Dominguez, R.; Carlos-Reyes, A.; Lopez-Gonzalez, J.S.; Chavez-Dominguez, R.; Lopez-Camarillo, C.; de la Hernadez, C.O.N. Contribution of angiogenesis to inflammation and cCancer. Front. Oncol. 2019, 9, 1399. [CrossRef] [PubMed]

36. Hartman, G.D.; Fraley, M.E.; Bilodeau, M.T. Kinase insert domain-containing receptor kinase inhibitors as anti-angiogenic agents. Expert Opin. Investig. Drugs 2002, 11, 737-745. [CrossRef]

37. Garcia-Aranda, M.I.; Marrero, P.; Gautier, B.; Martin-Martinez, M.; Inguimbert, N.; Vidal, M.; Garcia-Lopez, M.T.; Jimenez, M.A.; Gonzalez-Muniz, R.; Perez de Vega, M.J. Parallel solid-phase synthesis of a small library of linear and hydrocarbon-bridged analogues of VEGF81-91: Potential biological tools for studying the VEGF/VEGFR-1 interaction. Bioorg. Med. Chem. 2011, 19, 1978-1986. [CrossRef]

38. Garcia-Aranda, M.I.; Mirassou, Y.; Gautier, B.; Martin-Martinez, M.; Inguimbert, N.; Vidal, M.; Garcia-Lopez, M.T.; Jimenez, M.A.; Gonzalez-Muniz, R.; Perez de Vega, M.J. Disulfide and amide-bridged cyclic peptide analogues of the VEGF81-91 fragment: Synthesis, conformational analysis and biological evaluation. Bioorg. Med. Chem. 2011, 19, 7526-7533. [CrossRef]

39. García-Aranda, M.I.; González-López, S.; Santiveri, C.M.; Gagey-Eilstein, N.; Reille-Seroussi, M.; Martín-Martínez, M.; Inguimbert, N.; Vidal, M.; García-López, M.T.; Jiménez, M.A.; et al. Helical peptides from VEGF and Vammin hotspots for modulating the VEGF-VEGFR interaction. Org. Biomol. Chem. 2013, 11, 1896-1905. [CrossRef]

40. de Veer, S.J.; Weidmann, J.; Craik, D.J. Cyclotides as tools in chemical biology. Acc. Chem. Res. 2017, 50, 1557-1565. [CrossRef]

41. Chaudhuri, D.; Aboye, T.; Camarero, J.A.; Camarero, J.A.; Camarero, J.A. Using backbone-cyclized Cys-rich polypeptides as molecular scaffolds to target protein-protein interactions. Biochem. J. 2019, 476, 67-83. [CrossRef] [PubMed]

42. Ji, Y.; Majumder, S.; Millard, M.; Borra, R.; Bi, T.; Elnagar, A.Y.; Neamati, N.; Shekhtman, A.; Camarero, J.A. In vivo activation of the p53 tumor suppressor pathway by an engineered cyclotide. J. Am. Chem. Soc. 2013, 135, 11623-11633. [CrossRef] [PubMed]

43. Fang, W.-Y.; Dahiya, R.; Qin, H.-L.; Mourya, R.; Maharaj, S. Natural proline-rich cyclopolypeptides from marine organisms: Chemistry, synthetic methodologies and biological status. Mar. Drugs 2016, 14, 194. [CrossRef] [PubMed]

44. Ibrahim, A.H.; Attia, E.Z.; Hajjar, D.; Anany, M.A.; Desoukey, S.Y.; Fouad, M.A.; Kamel, M.S.; Id, H.W.; Gulder, T.A.M.; Abdelmohsen, U.R. New cytotoxic cyclic peptide from the marine sponge-associated Nocardiopsis sp. UR67. Mar. Drugs 2018, 16, 290. [CrossRef] [PubMed]

45. Duncan, S.J.; Gruschow, S.; Williams, D.H.; McNicholas, C.; Purewal, R.; Hajek, M.; Gerlitz, M.; Martin, S.; Wrigley, S.K.; Moore, M. Isolation and structure elucidation of Chlorofusin, a novel P53-MDM2 antagonist from a Fusarium sp. J. Am. Chem. Soc. 2001, 123, 554-560. [CrossRef] [PubMed]

46. Clark, R.C.; Lee, S.Y.; Searcey, M.; Boger, D.L. The isolation, total synthesis and structure elucidation of chlorofusin, a natural product inhibitor of the p53-MDM2 protein-protein interaction. Nat. Prod. Rep. 2009, 26, 465-477. [CrossRef] [PubMed]

47. Cominetti, M.M.D.; Goffin, S.A.; Raffel, E.; Turner, K.D.; Ramoutar, J.C.; O'Connell, M.A.; Howell, L.A.; Searcey, M. Identification of a new p53/MDM2 inhibitor motif inspired by studies of chlorofusin. Bioorg. Med. Chem. Lett. 2015, 25, 4878-4880. [CrossRef]

48. Simonetti, L.; Ivarsson, Y. Genetically encoded cyclic peptide phage display libraries. ACS Cent. Sci. 2020, 6, 336-338. [CrossRef]

49. Deshayes, K.; Corn, J. Exploring protein-protein interactions using peptide libraries displayed on phage. In Phage Display In Biotechnology and Drug Discovery; Sidhu, S.S., Geyer, C.R., Eds.; CRC Press: Boca Raton, FL, USA, 2015; Volume 14, pp. 181-204. ISBN 978-1-4398-36-50-7. [CrossRef]

50. Galan, A.; Horvatic, A.; Kules, J.; Guillemin, N.; Mrljak, V.; Bhide, M.; Comor, L. Library-based display technologies: Where do we stand? Int. Mol. BioSyst. 2016, 12, 2342-2358. [CrossRef]

51. Desimmie, B.A.; Humbert, M.; Lescrinier, E.; Hendrix, J.; Vets, S.; Gijsbers, R.; Ruprecht, R.M.; Dietrich, U.; Debyser, Z.; Christ, F. Phage display-directed discovery of LEDGF/p75 binding cyclic peptide inhibitors of HIV replication. Mol. Ther. 2012, 20, 2064-2075. [CrossRef]

52. Lipok, M.; Szlachcic, A.; Kindela, K.; Czyrek, A.; Otlewski, J. Identification of a peptide antagonist of the FGF1-FGFR1 signaling axis by phage display selection. FEBS Open Biol. 2019, 9, 914-924. [CrossRef] [PubMed]

53. Smith, J.M.; Vitali, F.; Archer, S.A.; Fasan, R. Modular assembly of macrocyclic organo-peptide hHybrids using synthetic and genetically encoded precursors. Angew.Chem. Int. Ed. 2011, 123, 5181-5186. [CrossRef] 
54. Owens, A.E.; Iannuzzelli, J.A.; Gu, Y.; Fasan, R. MOrPH-PhD: An integrated phage display platform for the discovery of functional genetically encoded peptide macrocycle. ACS Cent. Sci. 2020, 6, 368-381. [CrossRef] [PubMed]

55. Tavassoli, A.; Benkovic, S.J. Split-intein mediated circular ligation used in the synthesis of cyclic peptide libraries in E. coli. Nat. Protoc. 2007, 2, 1126-1133. [CrossRef]

56. Mistry, I.N.; Tavassoli, A. Reprogramming the transcriptional response to hypoxia with a chromosomally encoded cyclic peptide HIF-1 inhibitor. ACS Synth. Biol. 2017, 6, 518-527. [CrossRef]

57. Birts, C.N.; Nijjar, S.K.; Mardle, C.A.; Hoakwie, F.; Duriez, P.J.; Blaydes, J.P.; Tavassoli, A. A cyclic peptideinhibitor of C-terminal binding protein dimerization links metabolism with mitotic fidelity in breast cancer cells. Chem. Sci. 2013, 4, 3046-3057. [CrossRef]

58. Bionda, N.; Cryan, A.L.; Fasan, R. Bioinspired strategy for the ribosomal synthesis of thioether-bridged macrocyclic peptides in bacteria. ACS Chem. Biol. 2014, 9, 2008-2013. [CrossRef]

59. Bacon, K.; Blain, A.; Burroughs, M.; McArthrur, N.; Rao, B.M.; Menegatti, S. Isolation of chemically cyclized peptide binders using yeast surface display. ACS Comb. Sci. 2020, 22, 519-532. [CrossRef]

60. Pandya, P.; Sayers, R.O.; Ting, J.P.; Morshedian, S.; Torres, C.; Cudal, J.S.; Zhang, K.; Fitchett, J.R.; Zhang, Q.; Zhang, F.F.; et al. Integration of phage and yeast display platforms: A reliable and cost effective approach for binning of peptides as displayed on-phage. PLoS ONE 2020, 15, e0233961. [CrossRef]

61. Menegatti, S.; Hussain, M.; Naik, A.D.; Carbonell, R.G.; Rao, B.M. mRNA display selection and solid-phase synthesis of Fc-binding cyclic peptide affinity ligands. Biotechnol. Bioeng. 2013, 110, 857-870. [CrossRef]

62. Ma, Z.; Hartman, M.C.T. In vitro selection of unnatural cyclic peptide libraries via mRNA display. Methods Mol. Biol. 2012, 805, 367-390. [CrossRef] [PubMed]

63. Zimmermann, G.; Neri, D. DNA-encoded chemical libraries: Foundations and applications in lead discovery. Drug Discov. Today 2016, 21, 1828-1834. [CrossRef] [PubMed]

64. Sachdev, S.; Sidhu, G.A.W. No TitleDNA-emncoded peptide libraries and drug discovery. Anticancer. Drug Dev. 2002, 237-248. [CrossRef]

65. Zhu, Z.; Shaginian, A.; Grady, L.C.; O’Keeffe, T.; Shi, X.E.; Davie, C.P.; Simpson, G.L.; Messer, J.A.; Evindar, G.; Bream, R.N.; et al. Design and application of a DNA-encoded macrocyclic peptide library. ACS Chem. Biol. 2018, 13, 53-59. [CrossRef]

66. Wills, R.; Adebomi, V.; Raj, M. Site-selective peptide macrocyclization. ChemBioChem 2020. Ahead of Print. [CrossRef]

67. Lian, W.; Upadhyaya, P.; Rhodes, C.A.; Liu, Y.; Pei, D. Screening bicyclic peptide libraries for protein-protein interaction inhibitors: Discovery of a tumor necrosis factor- $\alpha$ antagonist. J. Am. Chem. Soc. 2013, 135, 11990-11995. [CrossRef]

68. Luo, Q.; Tao, Y.; Sheng, W.; Lu, J.; Wang, H. Dinitroimidazoles as bifunctional bioconjugation reagents for protein functionalization and peptide macrocyclization. Nat. Commun. 2019, 10, 142. [CrossRef]

69. Zhang, Y.; Zhang, Q.; Wong, C.T.T.; Li, X. Chemoselective Peptide Cyclization and Bicyclization Directly on Unprotected Peptides. J. Am. Chem. Soc. 2019, 141, 12274-12279. [CrossRef]

70. Reguera, L.; Rivera, D.G. Multicomponent Reaction Toolbox for Peptide Macrocyclization and Stapling. Chem. Rev. 2019, 119, 9836-9860. [CrossRef]

71. Neochoritis, C.G.; Miraki, M.K.; Abdelraheem, E.M.M.; Surmiak, E.; Zarganes-Tzitzikas, T.; Łabuzek, B.; Holak, T.A.; Domling, A. Design of indole- and MCR-based macrocycles as p53-MDM2 antagonists. Beilstein J. Org. Chem. 2019, 15, 513-520. [CrossRef]

72. Malins, L.R.; deGruyter, J.N.; Robbins, K.J.; Scola, P.M.; Eastgate, M.D.; Ghadiri, M.R.; Baran, P.S. Peptide macrocyclization inspired by non-ribosomal imine natural products. J. Am. Chem. Soc. 2017, 139, 5233-5241. [CrossRef] [PubMed]

73. Gueret, S.M.; Thavam, S.; Carbajo, R.J.; Potowski, M.; Larsson, N.; Dahl, G.; Dellsen, A.; Grossmann, T.N.; Plowright, A.T.; Valeur, E.; et al. Macrocyclic modalities combining peptide epitopes and natural product fragments. J. Am. Chem. Soc. 2020, 142, 4904-4915. [CrossRef] [PubMed]

74. Thombare, V.J.; Holden, J.A.; Reynolds, E.C.; O’Brien-Simpson, N.M.; Hutton, C.A. Celogentin mimetics as inhibitors of tubulin. J. Pep. Sci. 2020, 26, e3239. [CrossRef] [PubMed]

75. Bernhagen, D.; Jungbluth, V.; Quilis, N.G.; Dostalek, J.; White, P.B.; Jalink, K.; Timmermann, P. High-affinity $\alpha, \beta$-integrin-selective bicyclic RGD peptides identified via screening of designed random libraries. ACS Comb. Sci. 2019, 21, 598-607. [CrossRef] [PubMed]

76. Kubi, G.A.; Dougherty, P.G.; Pei, D. Designing cell-permeable macrocyclic peptides. Methods Mol. Biol. 2019, 2001, 41-59. [CrossRef]

77. Salim, H.; Song, J.; Sahni, A.; Pei, D. Development of a Cell-Permeable Cyclic Peptidyl Inhibitor against the Keap1-Nrf2 Interaction. J. Org. Chem. 2020, 85, 1416-1424. [CrossRef]

78. Colarusso, S.; De Simone, D.; Frattarelli, T.; Andreini, M.; Cerretani, M.; Missineo, A.; Moretti, D.; Tambone, S.; Kempf, G.; Augustin, M.; et al. Optimization of linear and cyclic peptide inhibitors of KEAP1-NRF2 protein-protein interaction. Bioorg. Med. Chem. 2020, 28, 115738. [CrossRef]

79. Dougherty, P.G.; Wen, J.; Pan, X.; Koley, A.; Ren, J.-G.; Sahni, A.; Basu, R.; Salim, H.; Appiah Kubi, G.; Qian, Z.; et al. Enhancing the cell permeability of stapled peptides with a cyclic cell-penetrating peptide. J. Med. Chem. 2019, 62, 10098-10107. [CrossRef]

80. Rhodes, C.A.; Dougherty, P.G.; Cooper, J.K.; Qian, Z.; Lindert, S.; Wang, Q.-E.; Pei, D. Cell-permeable bicyclic peptidyl inhibitors against NEMO-IкB kinase iInteraction directly from a combinatorial library. J. Am. Chem. Soc. 2018, 140, 12102-12110. [CrossRef] 
81. Fujiwara, D.; Kitada, H.; Oguri, M.; Nishihara, T.; Michigami, M.; Shiraishi, K.; Yuba, E.; Nakase, I.; Im, H.; Cho, S.; et al. A Cyclized helix-loop-helix peptide as a molecular scaffold for the design of inhibitors of intracellular protein-protein interactions by epitope and arginine grafting. Angew. Chem. Int. Ed. 2016, 55, 10612-10615. [CrossRef]

82. Hemmati, S.; Behzadipour, Y.; Haddad, M. Decoding the proteome of severe acute respiratory syndrome coronavirus 2 (SARSCoV-2) for cell-penetrating peptides involved in pathogenesis or applicable as drug delivery vectors. Infect. Genet. Evol. 2020, 85, 104474. [CrossRef] [PubMed]

83. Albert, L.; Vazquez, O. Photoswitchable peptides for spatiotemporal control of biological functions. Chem. Commun. 2019, 55, 10192-10213. [CrossRef] [PubMed]

84. Martin-Quiros, A.; Nevola, L.; Eckelt, K.; Madurga, S.; Gorostiza, P.; Giralt, E. Absence of a stable secondary structure is not a limitation for photoswitchable inhibitors of $\beta$-arrestin/ $\beta$-adaptin 2 protein-protein interaction. Chem. Biol. 2015, $22,31-37$. [CrossRef] [PubMed]

85. Nevola, L.; Varese, M.; Martin-Quiros, A.; Mari, G.; Eckelt, K.; Gorostiza, P.; Giralt, E. Targeted nanoswitchable inhibitors of protein-protein interactions involved in apoptosis. ChemMedChem 2019, 14, 100-106. [CrossRef] [PubMed]

86. Babii, O.; Afonin, S.; Ishchenko, A.Y.; Schober, T.; Negelia, A.O.; Tolstanova, G.M.; Garmanchuk, L.V.; Ostapchenko, L.I.; Komarov, I.V.; Ulrich, A.S. Structure-activity relationships of photoswitchable diarylethene based $\beta$-hairpin peptides as membranolytic antimicrobial and anticancer agents. J. Med. Chem. 2018, 61, 10793-10813. [CrossRef] [PubMed]

87. Afonin, S.; Babii, O.; Reuter, A.; Middel, V.; Takamiya, M.; Strähle, U.; Komarov, I.V.; Ulrich, A.S. Light-controllable dithienylethene-modified cyclic peptides: Photoswitching the in vivo toxicity in zebrafish embryos. Beilstein J. Org. Chem. 2020, 16, 39-49. [CrossRef] [PubMed]

88. Frackenpohl, J.; Arvidsson, P.I.; Schreiber, J.V.; Seebach, D. The Outstanding Biological Stability of beta-and-gamma-Peptides toward Proteolytic Enzymes: An In Vitro Investigation with Fifteen Peptidases. ChemBioChem. 2001, 2, 445-455. [CrossRef]

89. Peterson-Kaufman, K.J.; Haase, H.S.; Boersma, M.D.; Lee, E.F.; Fairlie, W.D.; Gellman, S.H. Residue-Based Preorganization of BH3-Derived $\alpha / \beta$-Peptides: Modulating Affinity, Selectivity and Proteolytic Susceptibility in $\alpha$-Helix Mimics. Chem. Biol. 2015, 10, 1667-1675. [CrossRef]

90. Fülöp, F.; Martinek, T.A.; Toth, G.K. Application of alicyclic $\beta$-amino acids in peptide chemistry. Chem. Soc. Rev. 2006, 35, 323. [CrossRef]

91. Kritzer, J.A.; Stephens, O.M.; Guarracino, D.A.; Reznika, S.K.; Schepartza, A. $\beta$-Peptides as inhibitors of protein-protein interactions. Bioorg. Med. Chem. 2005, 13, 11-16. [CrossRef]

92. Smith, B.J.; Lee, E.F.; Checco, J.W.; Evangelista, M.; Gellman, S.H.; Fairlie, W.D. Structure-guided rational design of $\alpha / \beta$-peptide foldamers with high affinity for BCL-2 family prosurvival proteins. ChemBioChem 2013, 14, 1564-1572. [CrossRef] [PubMed]

93. Haase, H.S.; Peterson-Kaufman, K.J.; Lan Levengood, S.K.; Checco, J.W.; Murphy, W.L.; Gellman, S.H. Extending Foldamer Design Beyond $\alpha$-Helix Mimicry: $\alpha / \beta$-Peptide inhibitors of vascular endothelial growth factor Signaling. J. Am. Chem. Soc. 2012, 134, 7652-7655. [CrossRef]

94. Bautista, A.D.; Appelbaum, J.S.; Craig, C.J.; Michel, J.; Schepartz, A. Bridged $\beta 3$-peptide inhibitors of p53-hDM2 complexation: Correlation between affinity and cell permeability. J. Am. Chem. Soc. 2010, 132, 2904-2906. [CrossRef] [PubMed]

95. Checco, J.W.; Lee, E.F.; Evangelista, M.; Sleebs, N.J.; Rogers, K.; Pettikiriarachchi, A.; Kershaw, N.J.; Eddinger, G.A.; Belair, D.G.; Wilson, J.L.; et al. $\alpha / \beta$-peptide foldamers targeting intracellular protein-protein interactions with activity in living cells. J. Am. Chem. Soc. 2015, 137, 11365-11375. [CrossRef] [PubMed]

96. Udugamasooriya, D.G.; Dineen, S.P.; Brekken, R.A.; Kodadek, T. A Peptoid "antibody surrogate" that antagonizes VEGF receptor 2 activity. J. Am. Chem. Soc. 2008, 130, 5744-5752. [CrossRef] [PubMed]

97. Mondragón, L.; Orzáez, M.; Sanclimens, G.; Moure, A.; Armiñán, A.; Sepúlveda, P.; Messeguer, A.; Vicent, M.J.; Pérez-Payá, E. Modulation of cellular apoptosis with apoptotic protease-activating factor 1 (Apaf-1) inhibitors. J. Med. Chem. 2008, 51, 521-529. [CrossRef] [PubMed]

98. Oh, M.; Lee, J.H.; Moon, H.; Hyun, Y.J.; Lim, H.S. A Chemical inhibitor of the Skp2/p300 Interaction that promotes p53-mediated apoptosis. Angew. Chem. Int. Ed. 2016, 11, 602-606. [CrossRef]

99. Drew, K.; Renfrew, P.D.; Craven, T.W.; Butterfoss, G.L.; Chou, F.-C.; Lyskov, S.; Bullock, B.N.; Watkins, A.; Labonte, J.W.; Pacella, M.; et al. Adding diverse noncanonical backbones to rosetta: Enabling peptidomimetic design. PLoS ONE 2013, 8, e67051. [CrossRef]

100. Schneider, J.A.; Craven, T.W.; Kasper, A.C.; Yun, C.; Haugbro, M.; Briggs, E.M.; Svetlov, V.; Nudler, E.; Knaut, H.; Bonneau, R.; et al. Design of Peptoid-peptide Macrocycles to Inhibit the $\beta$-catenin TCF Interaction in Prostate Cancer. Nature 2018, 9, 4396. [CrossRef]

101. Shin, M.H.; Lee, K.S.; Lim, H.-S. DNA-Encoded combinatorial library of macrocyclic peptoids. Bioconjugate Chem. 2019, 30, 2931-2938. [CrossRef]

102. Stone, T.A.; Deber, C.M. Therapeutic design of peptide modulators of protein-protein interactions in membranes. Biochim. Biophys. Acta 2017, 1859, 577-585. [CrossRef] [PubMed]

103. Messina, F.; Giombini, E.; Montaldo, C.; Sharma, A.A.; Piacentini, M.; Zoccoli, A.; Sekaly, R.-P.; Locatelli, F.; Zumla, A.; Maeurer, M.; et al. Looking for pathways related to COVID-19 phenotypes: Confirmation of pathogenic mechanisms by SARS-CoV-2-Host interactome. bioRxiv 2020, 1-23. [CrossRef] 
104. Bojadzic, D.; Alcazar, O.; Chen, J.; Buchwald, P. Small-molecule In Vitro inhibitors of the coronavirus spike-ACE2 protein-protein interaction as blockers of viral attachment and entry for SARS-CoV-2. bioRxiv 2020, 1-60. [CrossRef]

105. Cantuti-Castelvetri1, L.; Ojha, R.; Pedro, L.D.; Djannatian, M.; Franz, J.; Kuivanen, S.; van der Meer, F.; Kallio, K.; Kaya, T.; Anastasina, M.; et al. Neuropilin-1 facilitates SARS-CoV-2 cell entry and infectivity. Science 2020, 370, 856-860. [CrossRef]

106. Bello, M.; Martinez-Munoz, A.; Balbuena-Rebolledo, I. Identification of saquinavir as a potent inhibitor of dimeric SARS-CoV2 main protease through MM/GBSA. J. Mol. Model. 2020, 26, 340. [CrossRef] 